\title{
Optimalisasi Penggunaan WhatsApp dalam Perkuliahan Penilaian Pendidikan Fisika
}

\author{
Khusaini, Agus Suyudi, Winarto dan Sugiyanto \\ Jurusan Fisika FMIPA Universitas Negeri Malang \\ Jalan Semarang 5 Malang \\ Surat-e: Khusaini.fmipa@um.ac.id
}

Penelitian ini bertujuan untuk memberikan gambaran pentingnya penggunaan aplikasi online terutama WhatsApp (WA) dalam kegiatan pembelajaran terutama perkuliahan Penilaian Pendidikan Fisika. Tiga puluh dua responden yang terlibat dalam penelitian ini adalah calon guru fisika di jurusan fisika FMIPA UM. Metode pengumpulan data yang digunakan dalam kegiatan ini berupa angket, observasi dan wawancara. Hasil penelitian menunjukkan adanya pengaruh positif dari penggunaan WA bagi keaktifan mahasiswa dalam berdiskusi serta kuliah baik dalam perkuliahan tatap muka maupun dalam jaringan (daring). Mahasiswa juga merasa perlu untuk mencoba menerapkan penggunaan WA dalam kegiatan pembelajaran kelak maupun dalam perkuliahan lain. Kedekatan serta diskusi antar mahasiswa dan dosen-mahasiswa dapat terjadi dengan baik serta meningkatkan motivasi belajar mahasiswa. Penelitian ini juga menunjukkan perlunya penelitian lebih lanjut mengenai pengaruh penggunaan WA terhadap prestasi belajar mahasiswa.

This study aims to describe the importance of Online Application use particularly WhatsApp (WA) during learning activities in particular in a Physics Education Assessment lecture. Thirty-two respondents involved are pre-service Physics Teachers learning at Physics Department FMIPA UM. Questionnaire and interview were employed to obtain data about the importance of WA in the lecture. The study shows positive influences of WA application to students' activity during discussion section in both face-to-face meeting and online discussion. The participants also thought that they need to employ WA during both future Physics class and other lectures. The application also encouraged student discussion with their peer and also the lecturer. This study also indicates the need of further research about WA application and students' achievement.

Kata kunci: Optimalisasi, WhatsApp, Perkuliahan Penilaian Pendidikan Fisika

\section{Pendahuluan}

Perkembangan zaman telah mempengaruhi berbagai sendi kehidupan. Pengaruh perubahan zaman tersebut juga tidak dapat dihindari pada perkuliahan fisika terutama bagi calon guru fisika. Perkuliahan yang bersentuhan dengan calon guru fisika sudah selayaknya mendapatkan sentuhan yang berbeda untuk mempersiapkan calon guru yang siap beradaptasi dan mengendalikan perubahan zaman untuk kepentingan pembelajaran fisika yang efektif dan menarik.

Salah satu usaha untuk beradaptasi dengan perubahan zaman adalah optimalisasi penggunaan Teknologi, Informasi, dan Komunikasi (TIK) dalam kegiatan perkuliahan. Optimalisasi penggunaan sarana TIK ini diharapkan dapat mempersiapkan guru masa depan yang melek teknologi serta siap berperan dalam dunia yang semakin sempit dengan perkembangan TIK.

Perkembangan TIK yang sudah sangat terasa adalah komunikasi dan interaksi manusia secara maya dengan berbantuan internet. Komunikasi dan interaksi dalam media social ini terkadang memberikan manfaat akan tetapi tidak jarang akan menimbulkan dampak negatif bagi pengguna yang kurang bijaksana.

Sebagai pendidik masa depan, sudah sepatutnya seorang pendidik fisika mampu memanfaatkan segala yang tersedia dan berusaha mengubah potensi negatif menjadi bermanfaat dalam bidang pendidikan fisika. Potensi inilah yang dapat ditemukan dalam media sosial yang sudah 
menjamur bahkan mempengaruhi pola pikir masyarakat. Salah satu contoh media sosial yang sudah cukup menjamur bahkan hampir semua masyarakat telah menggunakannya adalah aplikasi WhatsApp. Aplikasi yang jumlah pennggunanya sudah bertambah banyak dari segala tingkat sosial.

Pengguna WA sudah menjamur dengan menduduki peringkat teratas. Bertambahnya jumlah pengguna ini tidak lepas dari mudahnya menunduh aplikasi dari Google Store maupun semakin banyaknya pengguna smartphone didunia terutama yang berjenis android. Manusia semakin mudah berinteraksi untuk mengirimkan pesan, berdiskusi, hingga membentuk grup tertentu untuk tujuan tertentu. Hal ini juga tidak lepas dari kecilnya usaha komersialisasi dari WA yang meniadakan iklan pada aplikasinya. Semakin bertambahnya pengguna inilah yang mendorong Facebook mengakuisisi perusahan tersebut pada tahun 2014 [I2].

Besarnya potensi WA tersebut, akan tetapi, masih belum terserap dan terpelajari dengan baik dalam dunia pendidikan fisika di Indonesia. Masyarakat pendidikan fisika masih belum mengeksplorasi dan berinteraksi dengan teknologi komunikasi terutama social media dalam kegiatan pembelajaran fisika. Pentingnya optimalisasi pemanfaatan WA dalam perkuliahan calon guru fisika inilah yang mendorong perlunya penelitian dalam penggaplikasian social media terutama WA untuk meningkatkan keprofesionaln guru fisika masa depan.

Penelitian ini berusaha memberikan gambaran awal pengaplikasian WA dalam perkuliahan Penilaian Pendidikan Fisika. Tulisan ini akan memberikan gambaran pentingnya interaksi dan peningkatan kualitas komunkasi antar mahasiswa serta interaksi dosenmahasiswa dalam kegiatan perkuliahan. Gambaran ini yang selanjutnya menjadi pemicu bagi menigkatnya profesionalitas guru fisika masa depan dalam melayani dan mendorong siswa dalam belajar fisika.

\section{Kajian Pustaka}

Sarana TIK yang digunakan dalam aktivitas sehari-hari diciptakan tidak murni untuk pendidikan. Namun, ketidakmurniaan ini memberikan tantangan bagi guru maupun dosen dalam bidang pendidikan fisika untuk mengeksplorasi keefektifan penggunaan TIK tersebut dalam kegiatan pembelajaran. Berbagai penelitian dilakukan untuk mengetahui dampak yang ditimbulkan oleh penerapan TIK dalam pembelajaran [I],[2],[3].

Dampak kegiatan pembelajaran yang menggunakan fasilitas dalam jaringan (daring) juga telah diteliti. Kaware dan San (2015) serta Wang (20II) menemukan bahwa penggunaan TIK dalam pembelajaran memberikan kesempatan lebih luas bagi siswa dalam mengakases sumber informasi untuk belajar [I],[4]. Lebih lanjut, pembelajaran dengan memanfaatkan TIK juga dapat memberikan manfaat bagi guru maupun dosen sebagai pengajar. Para pengajar dapat selalu meningkatkan tingkat keilmuan mereka dengan senantiasa belajar secara daring, berkolaborasi dengan teman sejawatnya secara daring, maupun mempersiapan pembelajarannya di kelas [4], [3].

Beberapa penelitian juga menunjukkan dua sisi peranan TIK dalam pembelajaran. TIK memberikan dampak positif bagi kegiatan pembelajaran dikelas termasuk fisika sebagai bagian dari rumpun ilmu alam pada beberapa penelitian meskipun dengan beberapa catatan $[5],[6],[7[8],[9]$. Penemuan tersebut berdasarkan penelitian yang dilakukan pada negara yang berbeda meliputi Nigeria, Cina, Inggris, dan Turki. Namun, Aina (2013) menemukan beberapa kelemahan dari penggunaan TIK dalam kegiatan pembelajaran. Kelemahan yang ditemukan oleh Aina merupakan berdasarkan pengalaman mengajar di negaranya (Nigeria) [IO].

Penelitian penggunaan TIK dalam pembelajaran banyak yang menekankan penggunaan murni dari pembelajaran dalam jaringan (online learning atau e-learning) [I], [3]. Penelitian tersebut menggambarkan bagaimana peranan yang sangat besar dari TIK dalam pembelajaran terutama pada zaman internet sekarang ini. Akan tetapi, pertemuan tatap muka sebaiknya diberikan porsi yang setara atau bahkan lebih terutama untuk calon guru fisika. Calon guru sebaiknya dapat memadukan kelas tradisional dengan kelas dalam jaringan.

Penekanan pentingnya gabungan pertemuan dikelas dengan pemanfaatan TIK dalam pembelajaran mendorong tim peneliti untuk meneliti penerapan perpaduan kegiatan dalam dan luar jaringan. Pentingnya blended learning sudah pernah diteliti oleh Megeid (20I4) pada mata pelajaran Akuntasi [3]. Dia menemukan bahwa metode ini memiliki nilai lebih jika dibandingkan dengan elearning. Kegiatan perkuliahan gabungan (blended learning) menawarkan kemudahan dan kefleksibelan TIK dengan pentingnya arti pertemuan dalam kelas. Megeid juga menemukan bahwa penerapan yang tepat pada pembelajaran blended dapat meningkatkan efektivitas kegiatan pembelajaran. Gabungan pembelajaran tatap muka dan pemebelajaran dalam jaringan ini diharapkan dapat memberikan nilai lebih dibandingkan dengan hanya menerapkannya secara terpisah.

Penelitian yang dilaksanakan bagi calon guru fisika dimungkinkan dapat memberikan dampak positif bagi calon guru maupun peningkatan mutu pembelajaran fisika ke depan. Para calon guru fisika dapat memperoleh perluasan akses ilmu pengetahuan pada bidang yang diajarkan. Calon guru tersebut juga dimungkinkan akan mengadopsi penggunaan metode pada kelas fisika yang akan diampunya di masa mendatang. Hasil yang mungkin didapatkan akhirnya adalah adanya peningkatan mutu pendidikan fisika di masa mendatang. 


\section{Metode Penelitian}

Penelitian ini menggunakan observasi, angket dan wawancara dalam usaha mengumpulkan data. Observasi dan angket yang digunakan pada pengumpulan data ini menggunakan pendekatan kualitatif sehingga bersifat terbuka dan memberikan kesempatan bagi responden untuk mengungkapkan pengalamn mereka selama mengikuti perkuliahan Penilaian Pendidikan Fisika dengan menggunakan blended learning yang menggunakan WA sebagai sarana komunikasi, diskusi, dan bertukar pikiran.

Tiga puluh dua orang responden terlibat dalam kegiatan penelitian ini. Semua responden merupakan mahasiswa jurusan fisika FMIPA UM yang sedang memprogram matakuliah pendidikan fisika yang sedang diampu oeh peneliti utama. Responden sebagian besar merupakan mahasiswa tahun ketiga (30 orang) dan sisanya merupakan mahasiswa tahun keempat yang sedang mengulang perkuliahan tersebut.

Angket yang digunakan dalam kegiatan penelitian ini disebarkan secara online. Mahasiswa memiliki kesempatan untuk memberikan respon maupun tidak. Mahasiswa memiliki kesempatan untuk merespon atau tidak dengan menggunakan angket tersebut. Mahasiswa dapat mengisi angket tersebut dengan membaca WA grup kelas dan langsung mengklik tautan yang disediakan. Klik yang dilakukan oleh mahasiswa pada tautan tersebut dapat langsung menghubungkan pada Google Formulir yang disediakan oleh tim peneliti. Mahasiswa memerlukan waktu sekitar IO menit untuk mengisi angket tersebut dan tidak ada batasan waktu atau tempat untuk mengisi angket tersebut. Akhirnya, 30 responden telah memberikan respon terhadap angket yang telah diberikan secara daring.

Wawancara dilakukan terhadap sepuluh orang yang terpilih. Keterpilihan responden berdasarkan pandangan awal mereka terhadap kegiatan pembelajaran blended yang dilakukan sebelum kegiatan perkuliahan. Responden mewakili kelompok mahasiswa yang sangat ingin mencoba penerapan pembelajaran blended, mahasiswa yang ingin menerapkan pembelajaran blended, dan tidak yakin pembelajaran blended memberikan manfaat dan sukses membentu mahasiswa dalam belajar selama perkuliahan. Kegiatan wawancara ini bersifat Focus Group Discussion (FGD) dengan dipimpin langsung oleh peneliti dalam kegiatan diskusi tersebut. Responden memilih hak penuh untuk berpendapat secara terbuka terhadap pertanyaan dari pewancara atau berpendapat terhadap pendapat temanna yang juga menjadi responden pada penelitian ini.

Kegiatan observasi merupakan salah satu metode pengumpulan data yang digunakan. Tim peneliti dibantu tiga orang pembantu lapangan melakukan pengamatan terhadap kegiatan perkuliahan di kelas. Observasi menggunakan model terbuka sebagai catatan lapangan untuk merekam semua fenomena yang dianggap menarik oleh pengamat selama kegiatan perkuliahan. Hasil pengamatan ini nanti akan dijadikan sebagai bahan pengaya hasil penelitian yang telah diperoleh pada angket dan wawancara. Kegiatan observasi ini dilakukan pada perkuliahan penilaian yang bersifat presentasi, dan mahasiswa/responden memiliki kesempatan untuk menilai penampilan teman sejawatnya.

\section{Hasil Penelitian dan Pembahasan}

Penelitian ini menunjukkan hasil yang menarik. Responden yang telah memberikan respon baik melalui angket, maupun wawancara memberikan balikan yang positif terhadap penerapan kegiatan perkuliahan dengan menggunakan sarana WA.

Hasil yang tidak begitu mengejutkan ditemukan melalui angket daring yang sudah disebarkan melalui Google Formulir. Seratus persen mahasiswa merasa terbantu dengan penggunaan WA sebagai sarana komunikasi dalam kegiatan pembelajaran. Responden juga menyatakan bahwa WA bermanfaat untuk komunikasi, diskusi, dan menanyakan permasalahan kuliah dengan teman sejawat maupun dosen. Komentar mahasiswa terhadap keterlaksanaan diskusi dengan menggunakan WA dapat dilihat pada tabel I dibawah ini.

Tabel I. Komentar responden terhadap penggunaan WA dalam kegiatan perkuliahan

\begin{tabular}{|c|c|}
\hline No & $\begin{array}{l}\text { Komentar dari "Penggunaan sarana WA membantu } \\
\text { komunikasi perkuliahan?" }\end{array}$ \\
\hline I & $\begin{array}{l}\text { Karena dengan aplikasi WA membantu kami apabila ingin } \\
\text { berdiskusi dngan bpk ibu dosen.. karena untuk tatap muka } \\
\text { langsung kadang sulit untuk dilakukan.. }\end{array}$ \\
\hline 2 & Membantu sekali \\
\hline 3 & $\begin{array}{l}\text { Karena adanya wa kita jadi lebih dekat dengan dosen dan tugas } \\
\text { / pemberitahuan soal kabar2 jadi lebih memudahkan. }\end{array}$ \\
\hline 4 & Bisa membagi banyak informasi \\
\hline 5 & $\begin{array}{l}\text { Sangat setuju, karena menurut saya media WA saat ini sudah } \\
\text { sangat umum untuk digunakan, jadi memudahkan kita untuk } \\
\text { mengetahui informasi melalui pesan yang dikirimkan lewat } \\
\text { WA }\end{array}$ \\
\hline 6 & $\begin{array}{l}\text { Dengan WA kita smua bisa sharing apapun sehingga tidak ada } \\
\text { miss komunikasi didalam kelas. }\end{array}$ \\
\hline 7 & sangat membantu sekali untuk share informasi \\
\hline 8 & sangat membantu \\
\hline 9 & $\begin{array}{l}\text { penggunaan wa snagat membantuuntuk tambahan informasi } \\
\text { selama perkuliahan, untuk share tugas dan infomasi-informasi } \\
\text { lain }\end{array}$ \\
\hline I0 & bisa tanya jika ada masukan dan permasalahan \\
\hline II & $\begin{array}{l}\text { Dengan adanya grup WA tentu sangat membantu karena } \\
\text { disitulah kita berbagi info, berkomunikasi, dan sharing bahan } \\
\text { perkuliahan }\end{array}$ \\
\hline $\mathrm{I} 2$ & $\begin{array}{l}\text { Jika ada hal yang ingin ditanyakan diluar jam perkuliahan, bisa } \\
\text { langsung ditanyakan }\end{array}$ \\
\hline 13 & Memudahkan komunikasi di luar jam pembelajaran \\
\hline 14 & karena adanya grup WA kita tidak akan ketinggalan informasi \\
\hline I5 & $\begin{array}{l}\text { Selain untuk berdiskusi, media WA digunakan untuk memberi } \\
\text { pengumuman mengenai perkuliahan yang akan dilakukan pada }\end{array}$ \\
\hline
\end{tabular}


No Komentar dari "Penggunaan sarana WA membantu komunikasi perkuliahan?"

perkuliahan selanjutnya sehingga kita bisa sedikit belajar sebelum perkuliahan dilakukan.

I6 Sangat membantu sekali untuk diskusi dan saling memberi pendapat antar teman

I7 Memudahkan berkomunikasi

I8 Lebih efisien dan fleksibel

I9 WA sangat membantu dalam melakukan peer assesment maupun dalam berdiskusi yang tidak harus bertatap muka

20 Membantu komunikasi

2I Mungkin lebih baik ketika grup Wa juga dijadikan sarana penilaian bagi tenaga pengajar.

22 WA sebagai sarana diskusi saat tidak dalam kuliah tatap muka

23 Mempermudah komunikasi

24 Mempermudah komunikasi dan lebih terbuka antar sesama mahasiswa maupun dengan dosen

25 membuat lebih mudah bertanya mendapat informasi secara lebih luas

26 lebih cepat memperoleh informasi dari mahasiswa lain maupun dosen

Berdasarkan komentar pada tabel I tersebut, dapat disimpulkan penggunaan WA dalam perkuliahan dapat membantu proses kemunikasi. Mahasiswa tidak hanya terbatas belajar di kelas dan dalam waktu tertentu. Mahasiswa dapat berkomunikasi lebih mudah dengan dosen untuk bertanya maupun berdiskusi baik secara umum di grup kelas maupun dengan dosen secara pribadi. Kemudahan komunikasi dan penyampaian informasi ini juga terekam dalam kegiatan wawancara. Mahasiswa peserta wawancara menyatakan semua akan mengaplikasikan penggunaan WA pada perkuliahan lain dan ketika mengajar fisika nanti jika memungkinkan.

Diskusi antar mahasiswa pun dapat berlangsung dengan baik karena mahasiswa dengan bebas dapat memberikan pertanyaan terhadap dosen maupun mahasiswa dalam grup. Diskusi dalam grup kelas dapat dilihat pada Gambar I. Ketika berdiskusi dan menemui permasalahan, mahasiswa dapat langsung bertanya kepada dosen maupun berkomentar terhadap jawaban dosen (lihat gambar 2)

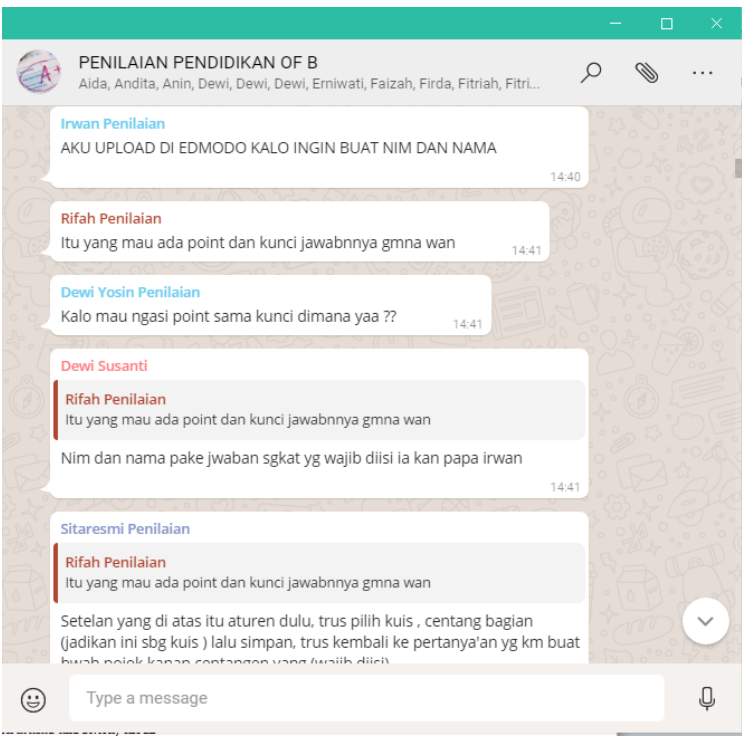

Gambar I. Diskusi antar mahasiswa dalam kegiatan perkuliahan
Kesempatan diskusi yang semakin luas dengan optamalisasi penggunaan WA ini dapat meningkatkan semangat belajar mahasiswa. Mahasiswa dapat langsung bertanya jika terdapat kekurangpahaman dalam topik tertentu.

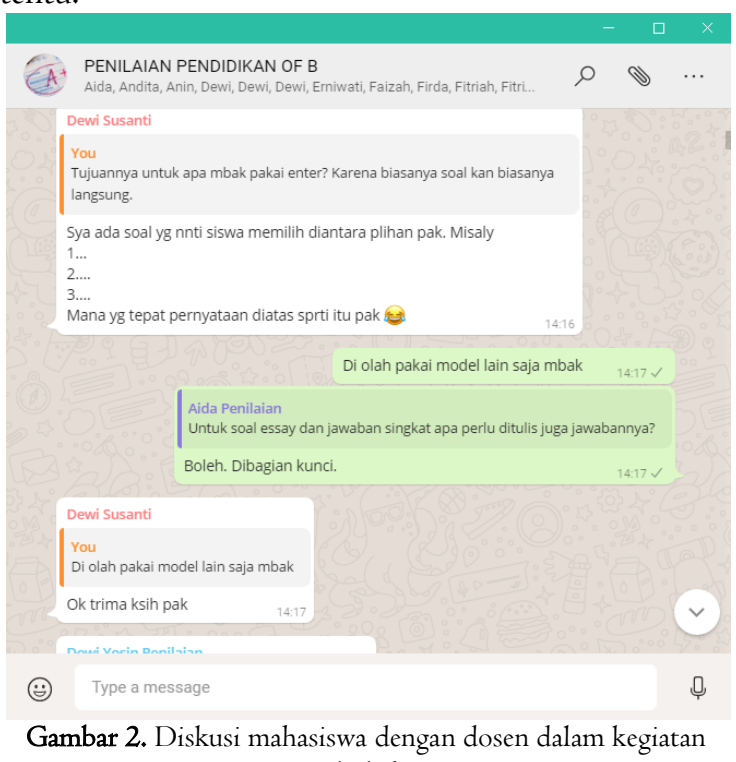
perkuliahan

Dosen juga dapat memberikan pengumuman terbaru melalui WA. Pengumuman terbaru ini dapat memberikan notifikasi langsung kepada mahasiwa sehingga mereka dapat langsung mengetahui informasi terbaru dalam kegiatan perkuliahan. Penggunaan dalam informasi ini dapat dilihat pada gambar 3. Penggunaan sarana WA untuk memberikan informasi terbaru ini juga mendapat respon yang bagus dari responden karena menghindarkan kesalahpamanan dan memberikan kemudahan dalam mengikuti perkuliahan berikutnya.

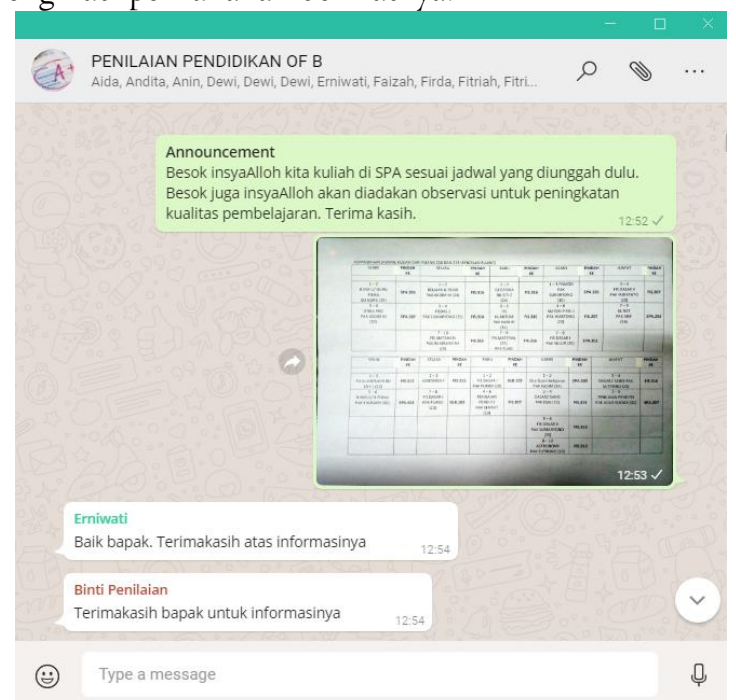

Gambar 3. Penggunaan WA sebagai tempat untuk memberikan pengumuman perkuliahan terbaru

Optimalisasi penggunaan WA untuk berbagi bahan ajar secara daring juga mendapat sambutan yang bagus dari mahasiswa. Semua mahasiswa setuju dengan 
pengunggahan bahan ajar atau sumber belajar secara daring. Kemudahan memperoleh bahan ini diharapkan responden (berdasarkan hasil wawancara) untuk terus dilanjutkan untuk mempermudah belajar dimanapun dan kapanpun. Komentar mahasiswa dalam penggunaan WA dalam berbagi buku dan file lain yang terkait dalam kegiatan perkuliahan penilaian pendidikan fisika dapat dilihat pada Tabel 2 .

Tabel 2. Komentar responden terhadap penggunaan WA dalam berbagi sumber belajar perkuliahan

No Komentar dari "Materi yang diupload di sarana WA/online memberi kemudahan dalam belajar?"

I Dngan aplikasi WA mempermudah kami mndapatkan informasi, seperti hasil presentasi dpat lngsung di share dngan cepat.

2 Mudah, jika paketannya dan jaringan wifi ada :)

3 Karena di wa sangat mudah untuk di akses maka itu cukup membantu.

4 Karena tidak perlu susah - susah untuk mendapat materi dari kelompok lainnya

5 Saya sangat setuju, karena dengan WA sangat mudah di akses.

6 Iya dengan mengupload materi semua siswa bisa tahu dan dapat mempelajarinya sendiri dimanapun dan kapanpun.

7 memudahkan karena dapat dipelajari secara langsung, jika kurang jelas dapat ditanyakan lewat WA

8 iya, membantu untuk belajar saya kedepannya dengan mengapload materi yang sudah dipelajari sehingga bisa saya pelajari lagi

9 ada mudahnya ada sulitnya

I0 materi yang di upload dapat membantu peserta didik lebih mudah dalam belajar dan tidak harus menunggu pembelajaran tatap muka

II bisa mengakses dimanapun, tetapi juga harus tetap memperhitungkan waktu pengerjaan

I2 Sangat memudahkan mahasiswa dalam mengakses materi perkuliahan yang didapat sehingga pembelajaran berlangsung secara efektif dan efisien

I3 Karena tidak hanya saat pembelajaran tatap muka saja kita bisa mendapatkan materi

I4 Mudah mendapatkan materi meskipun tidak waktunya jam pembelajaran

I5 karena kita tidak perlu bergantian minta ke salah satu teman yang mempuyai file ,

I6 Ya.. Materi yang diupload melalui WA membantu kita dalam proses belajar mandiri.

I7 Karena bisa membantu kita mempelajari materi yang mungkin kita lupa atau terlalu cepat dalam pembelajaran

I8 Memudahkan karna tidak harus meminta lwt flash disk

I9 Menghemat kertas dan terbindar dari virus di fd

20 materi yang diuplud lewat WA lebih efisien dan efektif, karena materinya bisa juga dipelajari lewat HP tidak harus membawa laptop

2I Bahan pembelajaran

22 Membantu dalam perkuliahan.

23 materi sangat membantu untuk dipelajari oleh mahasiswa dan dapat diakses secara mudah

24 Khususnya untuk materi yg akan dibahas sebaiknya dishare dulu supaya bisa persiapan hehe

25 Karena saat tatap muka mengejar jam jadi tidak sempat menulis semua bahan, dengan adanya fasilitas ini pembelajaran jadi lebih mudah

26 setuju

Penggunaan WA untuk sarana berbagi bahan ajar ini dapat dilakukan melalui laptop maupun smartphone.
Tersedianya pilihan untuk berbagi materi perkuliahan ini dapat meningkatkan kesempatan belajar dan berdiskui bagi mahasiswa dimanapun dan kapanpun. Contoh file sumber belajar yang diunggah di WA dapat dilihat pada Gambar 4. Kemudahan memperoleh bahan materi perkuliahan ini dapat meningkatkan motivasi mahasiswa dalam belajar dan meningkatkan potensinya dalam berkembang $[\mathrm{I}]$, [4].

Komentar dari responden pada tabel 2 dapat memberikan gambaran respon mahasiswa terhadap perluasan kesempatan belajar mahasiswa dengan berbagi materi perkuliahan. Mahasiswa secara garis besar dapat memperoleh kemudahan untuk mengakses bahan ajar serta lebih mudah untuk berdiskusi dan belajar.

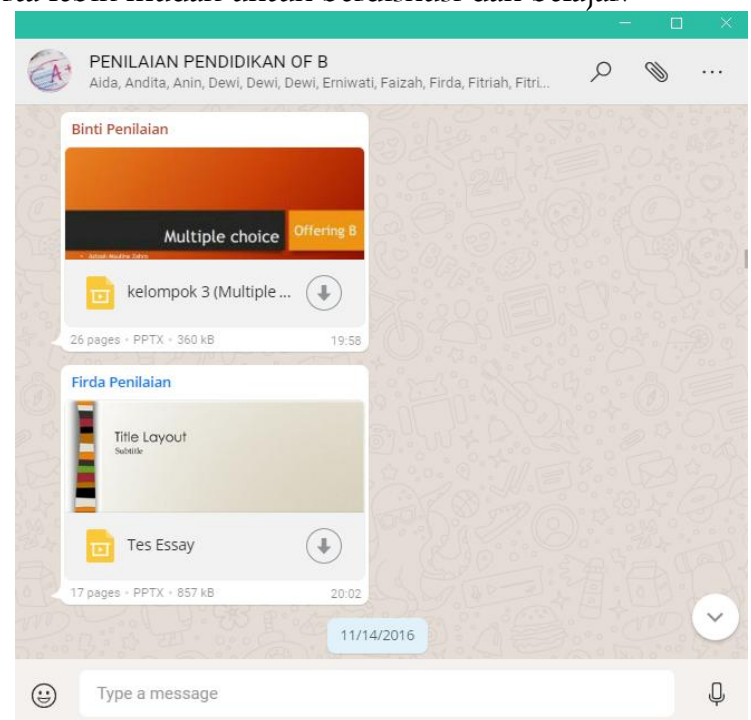

Gambar 4. Penggunaan WA sebagai tempat untuk berbagi bahan perkuliahan Penilaian Pendidikan Fisika

Pengoptimalan penggunaan WA juga dapat dilakukan dalam kegiatan penilaian teman sejawat. Mayoritas responden menunjukkan respon positif terhadap pelaksanaan teman sejawat dengan menggunakan WA. Hanya satu responden yang tidak setuju untuk menggunakan WA sebagai bahan penilaian teman sejawat karena terkendala sinyal, sisanya merasa terbantu dengan menggunakan WA sebagai alat penilaian teman sejawat untuk meningkatkan konsesntrasi dan perbaikan kualitas pembelajaran. Hasil wawancara juga menunjukkan penggunaan WA dalam penilaian teman sejawat membantu mahasiswa dalam menilai dan memudahkan untuk melihat hasil penilaian.

Berdasarkan pengamatan ketika kegiatan perkuliahan, penggunaan WA terlihat efektif membantu mahasiswa belajar dengan menggunakan penilaian teman sejawat. Mahasiswa pada awal penerapan masih terlihat bingung dalam melakukan kegiatan penilaian, namun semakin meningkat keefektifan kegiatan penilaian teman sejawat dengan berjalannya waktu. Perbaikan pembelajaran dengan menggunakan WA dilakukan pada pertemuan kedua setelah terdapat masukan dari pengamat terhadap 
kegiatan perkuliahan. Perbaikan berupa pemberian waktu tunggu oleh pengampuh perkuliahan untuk melihat hasil penilaian teman sejawat sehingga mahasiswa dapat membaca penilaian teman sejawatnya. Contoh penilaian teman sejawat ini dapat dilihat pada Gambar 4. Temuan ini sejalan dengan [II] yang juga melakukan penelitian dengan menggunakan WA sebagai fasilitas penilaian teman sejawat secara daring. Penelitian tersebut menunjukkan adanya peningkatan motivasi belajar serta perbaikan kualitas mengajar calon guru fisika.

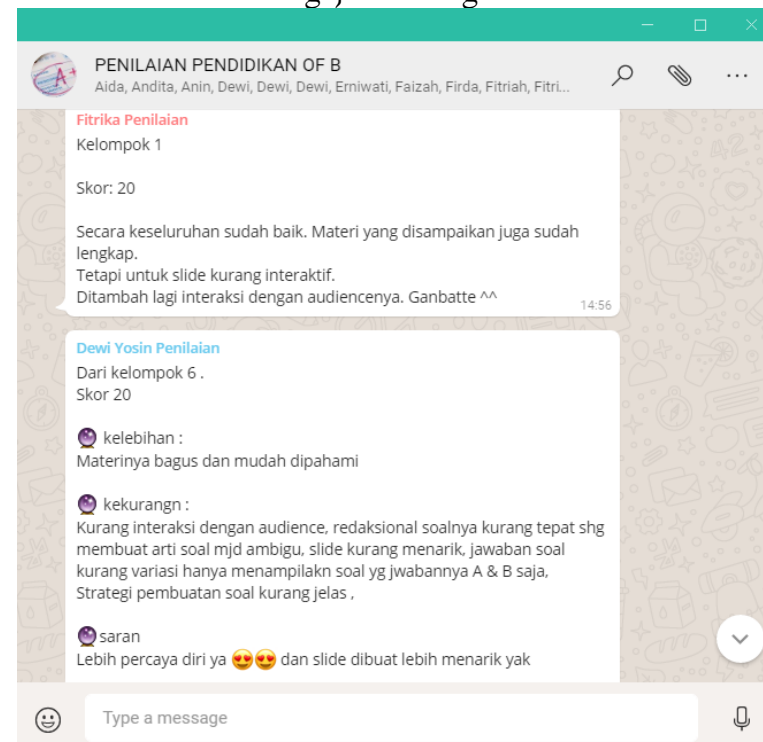

Gambar 4. Penggunaan WA sebagai tempat untuk menilai presentasi teman sejawat

Penggunaan penilaian sejawat secara daring ini membantu kegiatan belajar mahasiswa. Mahasiswa dapat secara langsung memperoleh penilaian dan masukan dari teman sejawatnya. Mahasiswa juga terlihat lebih aktif dalam menyimak dan memberikan balikan bagi perbaikan konsep dan penampilan mahasiswa lainnya.

Penggunaan WA sebagai media pembelajaran menunjukkan respon positif serta bermanfaat dalam kegiatan pembelajaran. Keefektifan ini disebabkan oleh mudahnya mengakses WA serta pesan bersifat instan. Penelitian lebih lebih lanjut mengenai penggunaan WA ini sebaiknya dilakukan dengan memfokuskan peranannya dalam meningkatkan prestasi belajar mahasiswa.

\section{Kesimpulan}

Penelitian mengenai pengoptimalan penggunaan WA menunjukkan beberapa peran positif dalam perkuliahan Penilaian Pendidikan Fisika. Penggunaan WA dalam perkuliahan dapat membantu mahasiswa berdiskusi dengan sesamanya maupun dengan dosen pengampuh perkuliahan. Kesempatan belajar maupun mengakses materi perkuliahan dapat berjalan lebih efektif serta dapat dilakukan kapanpun dan dimanapun. Penggunaan WA juga dapat dilakukan untuk melakukan penilaian teman sejawat. Mahasiswa dapat melakukan penilaian secara langsung serta dapat melihat masukan secara isntan tanpa harus menunggu waktu yang lama.

Penelitian lanjutan sebaiknya dilakukan untuk menyelidiki peranan penggunaan WA untuk meningkatkan prestasi belajar mahasiswa calon guru fisika. Peningkatan kualitas jaringan internet sebaiknya dilakukan untuk menjamin semakin optimalnya penggunaan TIK dalam pembelajaran fisika yang lebih menarik dan inovatif.

\section{Kepustakaan}

[I] Kaware, S. S., \& Sain, S. K. ICT Application in Education: An Overview.International Journal of Multidisciplinary Approach \& Studies, vol. 2, no. I, 2015, pp. 25-32.

[2] Brun, M., \& Hinostroza, J. E. Learning to become a teacher in the 2Ist century: ICT integration in Initial Teacher Education in Chile.Educational Technology \& Society, vol. I7, no. 3, 2014, pp. 222-238.

[3] Megeid, N. S. A. E-learning versus blended learning in accounting courses. Quarterly Review of Distance Education, vol.15, no. 2, 20I4, p. 35.

[4] Wang, T. Designing for designing: Information and communication technologies (ICTs) and professional education. International Journal of Att \& Design Education, vol.30, no.2, 2011, pp.188-199.

[5] Adeyemo, S. A.. The Impact of Information and Communication Technology (ICT) On Teaching and Learning of Physics. International Journal of Educational Research and Technology, vol.I, no.2, 2010, pp.48-59.

[6] Lee, S. M., Brescia, W., \& Kissinger, D. (2009). Computer use and academic development in secondary schools. Computers in the Schools, vol.26, no.3, 2009, pp. 224-235.

[7] Chang, C. Y., \& Cheng, W. Y. (2008). Science Achievement and Students' Self-confidence and Interest in Science: A Taiwanese representative sample study. International Journal of Science Education, vol.30, no.9, 2008, pp.II83-1200

[8] Voogt, J. IT and Curriculum Processes: Dilemmas and Challenges. In J. Voogt\& G. Knezek, Eds., International Handbook of Information Technology in Primary and Secondary Education, 2008, pp. I17-I32.

[9] Delen, E., \& Bulut, O. (201I). The Relationship between Students' Exposure to Technology and Their Achievement in Science and Math. TOJET: The Turkish Online Journal of Educational Technology, vol.10, no.3, 20I I, pp. 3II-3I7

[10] Aina, J. C. (20I3). Integration of ICT into Physics Learning to Improve Students' Academic Achievement: Problems and Solutions. Open Journal of Education, vol.1, no.4, 2011, pp. II7-I2I.

[II] Khusaini. Online Peer-Assessment in Teaching Physics in English class for improving pre-service physics teachers learning. Proceeding of 3rd International Conference on Research, Implementation and Education of Education of Mathematics and Science. Yogyakarta, Mei 2016.

[12] Rina. Dewi, Akuisisi facebook terhadapa WhatsApp Rampung, 2014.

http://m.tempo.co/read/news/2014/10/07/090612453/ak uisisi-facebook-terhadap-whatsapp-rampung diakses tanggal 3 Maret 20II. 